\title{
PHYTOCHEMICAL STUDY, TOXICITY AND ANTIMICROBIAL ACTIVITY OF Psidium myrsinites DC. (MYRTACEAE) LEAVES
}

\author{
ESTUDO FITOQUÍMICO, TOXICIDADE E ATIVIDADE ANTIMICROBIANA DAS \\ FOLHAS DE Psidium myrsinites DC. (MYRTACEAE)
}

\author{
Emanuelle Rosário Brito Durães ${ }^{1}$; Cássia de Oliveira Clementino ${ }^{1}$; Leonardo Rodrigues Fari ${ }^{1}$; \\ Luciana Machado Ramos ${ }^{1}$; Marilene Silva Oliveira ${ }^{1}$; Joelma Abadia Marciano de Paula ${ }^{1}$; \\ Plínio Lázaro Faleiro Naves ${ }^{1}$ \\ 1. Campus of Exact and Technological Sciences, State University of Goiás, Anápolis, GO, Brazil. plinionaves@ueg.br
}

\begin{abstract}
Psidium myrsinites DC. is species known as "araçá", from the Cerrado (savanna) biome in Brazil. It is commonly used as a medicinal plant in the treatment of diarrhea because of its astringent properties. The aims of this study were to carry out phytochemical screening with an exploratory purpose; to investigate toxicity by brine shrimp (Artemia salina) lethality bioassay; and to evaluate antimicrobial activity against Gram-positive and Gram-negative bacteria by determining the minimum inhibitory concentration of the essential oil, acetonic and ethanolic crude extracts, and the fractions obtained with organic solvents of Psidium myrsinites DC. leaves. The phytochemical profile determined the major classes of secondary metabolites present as phenolic compounds (tannins, coumarins, flavonoids, anthraquinone glycosides and terpene compounds). The essential oil and hexane fraction demonstrated a level of strong and mild toxicity respectively, thus encouraging further research with isolated substances from them. The crude ethanolic and acetonic extracts, and hexane fractions, chloroform intermediary, ethyl acetate and aqueous fraction from crude acetonic extract showed the best inhibitory effect on bacterial growth of Gram-positive bacteria with minimum inhibitory concentrations ranging between 62.5 and $250 \mu \mathrm{g} \cdot \mathrm{mL}^{-1}$. However, the presence of secondary compounds such as tannins, flavonoids and terpenes is probably associated with the inhibitory effect on tested microorganisms, which could justify the medicinal use of the leaves of this species.
\end{abstract}

KEYWORDS: Psidium myrsinites DC. Essential oils. Tannins. Artemia salina. Minimum inhibitory concentration.

\section{INTRODUCTION}

The Myrtaceae family is worldwide considered one of the largest botanical families. According to Franzon et al. (2009), it includes more than 4000 species in about 140 genera distributed around the world. Among all the genera of this family that include fruiting, four currently have economic importance: Eugenia, Acca, Myrciaria and Psidium.

The last one of these genera includes the species known in Brazil as "araçazeiros". In the Central West region of Brazil the following "araçá" species have been observed: Psidium laruotteanum Cambess., $P$. firmum O.Berg, Psidium guineense Sw, $P$. sartorianum, $P$. salutare (Kunth) O.Berg., and $P$. myrsinites DC. (FRAZON et al., 2009). They occur in areas under conditions of constant abiotic stress, including water and extreme temperatures (COELHO et al., 2004), a fact which, among other things, makes their fruits and leaves potentially rich in secondary metabolites, and thus they present different functional properties. Species rich in phenolic compounds, ascorbic acid and carotenes are often associated with important biological properties such as increased cellular protection against oxidation, antimicrobial and anticancer activities (MEDINA et al., 2011).

An ethnobotanical survey carried out by Campos (2010) reports that the inhabitants of urban areas, of rural settlements and of traditional "quilombolas" (communities of the descendants of freed or escaped slaves) in the Cerrado biome of Goiás state use the leaves and shoots of species of araçá to treat diarrhea. Data published by other authors reinforce the pharmacological potential of araçá leaves and fruits (FAUTH et al., 2002; MEDINA et al., 2011; VOSS-RECH et al., 2011; CORRÊA et al., 2011; OLIVEIRA et al., 2012; PATEL, 2012).

Among the species mentioned above, Psidium myrsinites DC. is the subject of this investigation. Known popularly as "araçá", it is a fruit tree native to Brazil, in the form of a tree crown with branches and glabrous terminal buds. The trunk circumference is about $21 \mathrm{~cm}$, gray or brown in color, smooth, with depressions that come off the trunk. Its leaves are simple, opposite, cross and elliptical. Some have visible laminar glands and are lighter on the underside, and exhale a pleasant smell when the leaves are crushed (SILVA JÚNIOR, 
2005; SOARES-SILVA; PROENÇA， 2008; FRANZON et al., 2009).

The fruits of $P$. myrsinites species are used in popular medicine for cicatrization and against diarrhea due to their astringent properties, and from the leaves is extracted an important substance for the cosmetics and perfume industry, linalool, used as a fixative. However, few studies have been carried out to validate the pharmacological activities and elucidate the chemical composition of this species (FRANZON et al., 2009).

In a study by Pereira (2010), P. myrsinites is related with three possible chemotypes, and the results of that research indicate that the essential oils obtained from the leaves of this species present antimicrobial activity, mainly against Gram-positive lineages. In research by Dias (2015), the essential oil of the leaves of this species presented larvicidal activity against the larvae of the mosquito Aedes aegypti L. Another recent study demonstrates antioxidant activity by the hydro-alcoholic extract of the leaves of this species (LEITE et al., 2016).

In this context, the aim of this study was to perform exploratory phytochemical screening, to investigate the toxicity and antimicrobial activity of the Essential Oil (EO), Crude Acetonic Extract (CAE) and Crude Ethanolic Extract (CEE), and fractions of $P$. myrsinites leaves.

\section{MATERIAL AND METHODS}

\section{Plant material}

The leaf samples of $P$. myrsinites were collected in the city of Anápolis, state of Goiás, in three locations on the Campus de Ciências Exatas e Tecnológicas of the Universidade Estadual de Goiás (UEG) (latitude 16²2'54,336"S, longitude $48^{\circ} 56^{\prime} 44,628^{\prime \prime} \mathrm{W} 1130$ meters of altitude, latitude $16^{\circ} 22^{\prime} 38,316^{\prime \prime} \mathrm{S}$, longitude $48^{\circ} 56^{\prime} 50,496^{\prime \prime} \mathrm{W}, 1144$ meters of altitude, latitude $16^{\circ} 22^{\prime} 38,316^{\prime \prime} \mathrm{S}$, longitude $48^{\circ} 56^{\prime} 50,820^{\prime \prime} \mathrm{W}, 1091$ meters above sea level) in January and February of 2015.

The leaves were air-dried at room temperature $\left(20-25^{\circ} \mathrm{C}\right)$ in a ventilated place for a week, ground into a powder and stored in a cool dry place. Three samples of plant material in voucher specimen were identified by Professor Mirley Luciene Santos and deposited in the herbarium of this institution under HUEG10046, HUEG10047 and HUEG10048 records.

\section{Essential oil}

The extraction of the essential oil of $P$. myrsinites leaves was performed by hydrodistillation method with Clevenger-type apparatus in approximately $200 \mathrm{~g}$ of desiccated and powdered plant material, kept for two hours. The essential oil obtained was dried over anhydrous sodium sulphate and stored under $\mathrm{N}_{2}$ in amber glass bottle, tightly sealed, at $-20^{\circ} \mathrm{C}$.

The essential oil was subjected to analysis by gas chromatography coupled to mass spectrometry (GC/MS) in Shimadzu QP5050A equipment at the Institute of Chemistry of the Universidade Federal de Goiás. A capillary column of fused silica was used (CBP - 5; 30m x $0.25 \mathrm{~mm} \times$ $0.25 \mu \mathrm{m}$ ), maintaining a flow rate of $1 \mathrm{~mL} / \mathrm{min}$ of helium as carrier gas, heating with programmed temperature $\left(60^{\circ} \mathrm{C} / 2 \mathrm{~min} ; 3^{\circ} \mathrm{C} \min ^{-1} / 240^{\circ} \mathrm{C}, 10^{\circ} \mathrm{C}\right.$ $\left.\min ^{-1} / 280^{\circ} \mathrm{C} 280^{\circ} \mathrm{C} / 10 \mathrm{~min}\right)$, and ionization energy of $70 \mathrm{eV}$. The injection volume was $1 \mu \mathrm{L}$ of diluted sample in $\mathrm{CH}_{2} \mathrm{Cl}_{2}$ in a ratio of 1:5.

The chemical components of the essential oils were identified by comparing their mass spectra and arithmetic contents to the literature (ADAMS, 2007). Co-injection of a series of alkanes from 9 to 32 carbons for use in the calculation of the arithmetic index according to the Van der Dool and Kratz (1963) equation was performed.

\section{Extracts and fractions}

Acetonic Extract

The CAE was prepared by maceration method using $500 \mathrm{~g}$ of powdered plant material in 8 liters of acetone/water $50 \%$ for Unique ultrasonic bath - Ultrasonic Cleaner with heating at $25^{\circ} \mathrm{C}$ in 8 sequential extractions of 30 minutes each followed by simple filtration with cotton. The acetonic extract was submitted to roto-evaporation in order to remove the solvent and the aqueous part stored at $20^{\circ} \mathrm{C}$ (CHAIBUB, 2013).

Fractions were obtained from the partition of the aqueous extract with ethyl acetate in a separatory funnel. The solvent was recovered and the aqueous fractions combined and lyophilized giving a yield of $36.93 \mathrm{~g}$.

\section{Ethanolic Extract}

The CEE was obtained by extraction of powdered leaves of $P$. myrsinites $(1000 \mathrm{~g}$ ) with ethanol P.A. in percolator until the saturation of the solvent (approximately 8 liters). The ethanolic extract was submitted to roto-evaporation in order to remove the solvent at $40^{\circ} \mathrm{C}$.

Fractions were obtained from $50 \mathrm{~g}$ of the dried crude ethanolic extract solubilized in $250 \mathrm{~mL}$ of methanol:water (7:3) with organic solvents of increasing polarity; the solubilized extract was treated three times, using $100 \mathrm{~mL}$ portions with each solvent, first with hexane, chloroform and finally ethyl acetate. 
The samples were concentrated using a rotary evaporation and stored at $-20^{\circ} \mathrm{C}$. Partitioned extracts, after drying, were weighed and the yields calculated for obtaining the hexane fraction $5.3 \mathrm{~g}$ $(5.3 \%), 0.9 \mathrm{~g}$ chloroform fraction $(0.9 \%)$, ethyl acetate fraction $5.6 \mathrm{~g}(5.6 \%)$. Upon partition with chloroform a third phase was observed in the separating funnel, and this probably corresponded to complex substances with a more apolar portion similar to the chloroform, while the other, more polar, was the aqueous part. Therefore, this phase was collected and called Intermediate of chloroform, which obtained a yield of $3.6 \mathrm{~g}$ (3.6\%).

\section{Preliminary phytochemical analysis}

The phytochemical screening was done according to the proposed methodology adapted from Costa (2001), Matos (2009), Matos and Matos (1989) and Falkenberg, Santos \& Simões (2010).

\section{Toxicity Assay}

The assay was performed according to methodology adapted from Molinas-Salinas and Said-Fernandez, 2006. Briefly, $250 \mathrm{mg}$ of Artemia salina cysts were incubated in a separating funnel containing $400 \mathrm{ml}$ medium in synthetic sea water prepared by dissolving sea salt $\left(40 \mathrm{~g} . \mathrm{L}^{-1}\right)$ and supplemented with yeast extract $\left(6 \mathrm{mg} . \mathrm{L}^{-1}\right)$. For hatching the cysts, the medium was maintained under constant oxygen saturation for a period of thirty-six hours at environmental temperature and natural light.

After hatching, the nauplii were attracted to the light source and were pipetted and transferred to a Petri dish with fresh media. The bioassay was carried out in 96-well polystyrene microplates with the following concentrations: 23,$040 ; 11,520 ; 5,760$; 2,$880 ; 1,440$ and $720 \mu \mathrm{g} \cdot \mathrm{mL}^{-1}$ in acetonic and ethanolic crude extracts; $500 ; 250 ; 125 ; 62.5 ; 31.25$ and $15.62 \mu \mathrm{g} . \mathrm{mL}^{-1}$ in the essential oil and 2,000; 1,$000 ; 500 ; 250 ; 125$ and $62.5 \mu \mathrm{g} . \mathrm{mL}^{-1}$ in the other fractions obtained from crude extracts. The nauplii were distributed on a standardized plate (MOLINAS-SALINAS; SAID-FERNANDEZ, 2006). Nauplii viability control, and negative and lethality controls using serial dilutions of $\mathrm{K}_{2} \mathrm{Cr}_{2} \mathrm{O}_{7}$ were included in the assays. The results allowed the calculation of the lethal concentration to $50 \%$ of the larvae $\left(\mathrm{LC}_{50}\right)$ by Probit method in the StatPlus 2009 professional program (AnalystSoft).

For the classification of the level of toxicity, we used the criteria proposed by Nguta et al. (2011). The authors categorize strong toxicity $\mathrm{LC}_{50}$ values up to $100 \mu \mathrm{g} \cdot \mathrm{mL}^{-1}$, moderate toxicity $\mathrm{LC}_{50}$ between 100 and $500 \mu \mathrm{g} \cdot \mathrm{ml}^{-1}$ and low toxicity $\mathrm{LC}_{50}$ between
500 and $1,000 \mu \mathrm{g} \cdot \mathrm{mL}^{-1}$, and nontoxic above 1,000 $\mu \mathrm{g} . \mathrm{mL}^{-1}$.

\section{Antimicrobial Activity}

Minimum inhibitory concentration (MIC) of the compounds of the microdilution protocols broth were standardized by the Clinical and Laboratory Standards Institute (CLSI M7-A6, 2010) against the following microorganisms: Staphylococcus aureus ATCC 29213, Staphylococcus aureus ATCC 25923, Staphylococcus epidermidis ATCC 12228, Escherichia coli ATCC 25312, Klebsiella pneumoniae ATCC 700603 and Pseudomonas aeruginosa ATCC 27853.

In summary, the bacterial cell suspensions were prepared from fresh cultures in Mueller Hinton agar according to the reference protocols. The compounds were diluted in dimethylsulfoxide (DMSO) to achieve five different concentrations used in the assay $(2.000,1.000,500,250,62.5$ $\left.\mu \mathrm{g} \cdot \mathrm{mL}^{-1}\right)$.

The readings of the tests for bacteria were performed after twenty-two hours of incubation at $35^{\circ} \mathrm{C}$ using clouding of view before adding resazurin, where the increase in turbidity or opacity in the medium indicates the growth of microorganisms (LENNETTE et al., 1985) and after adding resazurin, they were incubated for two more hours.

The reading of the results for MIC determination was considered as positive for the wells that remained blue, and for those that turned an intense pink color (PEREIRA, 2010). The following controls were prepared: statements, feasibility and diluent control.

\section{RESULTS AND DISCUSSION}

\section{Phytochemical Analysis}

The phytochemical study identified tannins, saponins, flavonoids, antraquinone glycosides, coumarins and terpenes and/or steroids; however, it did not detect alkaloids. As well as $P$. myrsinites, other species from the Psidium genus presented positive results for the presence of tannins, flavonoids and terpenes (IHA et al., 2008; SCUR et al., 2016; ALVARENDA et al., 2015).

\section{Essential Oil}

The yield of essential oil extraction from $P$. myrsinites was $1.74 \%$. In the analysis of the essential oil composition it was possible to identify 24 substances. The main compounds were: Ecaryophyllene $(31.01 \%), \alpha$-humulene $(12.32 \%)$ and caryophyllene oxide $(7.33 \%)$. The most prevalent 
constituents of the essential oil were sesquiterpenes $(57.87 \%)$.

According to Medeiros (2014), which performed an extraction of oil from leaves of $P$. myrsinites for three hours, the main compounds obtained were very similar to that study, caryophyllene oxide $(26.10 \%)$, epoxide humulene II $(8.80 \%)$ and $\beta$-caryophyllene $(7.40 \%)$. (E) $-\beta$ caryophyllene $(26.05 \%), \alpha$-humulene $(23.92 \%)$ and caryophyllene oxide $(10.09 \%)$ were also found in a study by Dias (2015) as main compounds, and the first two compounds were also found in the research carried out by Maia et al. (2010), (E) - $\beta$ caryophyllene $(28.70 \%)$ and $\alpha$-humulene $(19.40 \%)$.

Freitas, Morais and Silveira (2002) studied $P$. myrsinoides Berg O., showing that the oil is very similar to that of $P$. myrsinites, and $\beta$-caryophyllene $(22.40 \%)$ and caryophyllene oxide $(5.40 \%)$ are the major compounds. When comparisons are made with the data from the literature on the same species, significant differences are due to the fact that the variables (genetic and environmental) that influence the quantity and essential oil quality are diverse and difficult to control when it comes to individuals in their natural habitat (PAULA et al., 2011).

\section{Toxicity}

Table 1 shows the results of the toxicity of the samples and their 50\% lethal concentrations against $A$. salina. CEE presented $\mathrm{LC}_{50}$ of $11,336.90$ $\mu \mathrm{g} . \mathrm{mL}^{-1}$, while for the CAE, the $\mathrm{LC}_{50}$ was $6,389.60$ $\mu \mathrm{g} . \mathrm{mL}^{-1}$ and $\mathrm{EO}$ the $\mathrm{LC}_{50}$ of $95.30 \mu \mathrm{g} \cdot \mathrm{mL}^{-1}$.

Table 1. $\mathrm{CL}_{50}$ of extracts and fractions obtained from the leaves of $P$. myrsinites against A. salina.

\begin{tabular}{ccc}
\hline Samples & LC $_{\mathbf{5 0}}\left(\boldsymbol{\mu g} . \mathbf{m L}^{-\mathbf{1}}\right)$ & $\begin{array}{c}\text { Toxicity Level } \\
\text { Nguta et al. (2011) }\end{array}$ \\
\hline Extracts & & Strong \\
Essential Oil & 95.30 & Non-toxic \\
Crude Acetonic Extract & $6,389.60$ & Non-toxic \\
Crude Ethanolic Extract & $11,336.90$ & \\
Fractions & & Moderate \\
Hexane & 205.70 & Non-toxic \\
Chloroform & $1,323.30$ & Non-toxic \\
Intermediate Chloroform & $1,329.30$ & Non-toxic \\
Ethyl Acetate & $1,582.10$ & \\
\hline
\end{tabular}

$\mathbf{L C}_{\mathbf{5 0}}$ : Lethal Concentration $50 \%$ to A. salina.

According to Rahman et al. (2005), bioactive compounds are generally toxic to larvae of A. salina, and thus the lethality test is a simple lowcost method used to identify samples that purportedly contain bioactive substances. In toxicity tests fractions with hexane, chloroform, intermediate of chloroform and ethyl acetate obtained from the partition with $\mathrm{CEE}$, the results of $\mathrm{LC}_{50}$ were 205.70; 1,323.30; 1,329.30 and 1,582.10, respectively.

According to the results, only the essential oil obtained from $P$. myrsinites leaves showed strong toxicity $\left(\mathrm{LC}_{50}\right.$ to $\left.100 \mu \mathrm{g} \cdot \mathrm{mL}^{-1}\right)$. The table also showed that among the fractions, only the one obtained with hexane achieved considerable activity $\left(\mathrm{LC}_{50}\right.$ between 100 and $500 \mu \mathrm{g} \cdot \mathrm{mL}^{-1}$ ), while the other fractions and crude extracts were shown to be non-toxic in the test with $A$. salina. A study with Psidium guajava L. and Psidium guineense Sw. employed the same methodology in order to determine the $\mathrm{LC}_{50}$ concentration of ethyl acetate fraction obtained from ethanolic extracts of fruits at maturity, when green and ripe, using peel and pulp. However, the values found classified the fractions of both species as moderately toxic, with values of $181.40 \mu \mathrm{g} \cdot \mathrm{mL}^{-1}$ and $221.30 \mu \mathrm{g} . \mathrm{mL}^{-1} \quad$ (SÁNCHEZ; NEIRA, 2005).

\section{Antimicrobial activity}

Based on the literature data and in accordance with the MIC results (Table 2), the assay showed considerable results against Gram-positive strains. Through visual reading, therefore, it was observed that against Gram-negative bacteria there was no antimicrobial activity at concentrations below 2,000 $\mu \mathrm{g} . \mathrm{mL}^{-1}$ of sample, and the reading in a spectrophotometer was probably compromised by the presence of non-specific binding of resazurin, with pigments and other molecules present in plant extracts, making it infeasible to evaluate the results obtained with the spectrophotometer.

The obtained results were classified according to Holetz et al. (2002), as: good antimicrobial activity - MIC values up to 100 $\mu \mathrm{g} . \mathrm{mL}^{-1}$; moderate antimicrobial activity - MIC between 100 and $500 \mu \mathrm{g} \cdot \mathrm{mL}^{-1}$, weak activity - MIC between 500 and $1,000 \mu \mathrm{g} \cdot \mathrm{mL}^{-1}$ and sample with 
inactive antimicrobial activity - MIC above 1,000 $\mu \mathrm{g} \cdot \mathrm{mL}^{-1}$.

Table 2. MIC ( $\left.\mu \mathrm{g} \cdot \mathrm{mL}^{-1}\right)$ of essential oil and ethanolic and acetonic crude extracts of $P$. myrsinites leaves against Gram-positive and Gram-negative bacteria.

\begin{tabular}{lccc}
\hline Bacteria & EO & CAE & CEE \\
\hline Staphylococcus aureus ATCC 29213 & $\geq 2,000$ & 250 & 500 \\
Staphylococcus aureus ATCC 25923 & $\geq 2,000$ & 125 & 125 \\
Staphylococcus epidermidis ATCC 12228 & $\geq 2,000$ & 62.50 & 125 \\
Escherichia coli ATCC 25312 & $\geq 2,000$ & $\geq 2,000$ & $\geq 2,000$ \\
Klebsiella pneumoniae ATCC 700603 & $\geq 2,000$ & $\geq 2,000$ & $\geq 2,000$ \\
Pseudomonas aeruginosa ATCC 27853 & $\geq 2,000$ & $\geq 2,000$ & $\geq 2,000$ \\
\hline
\end{tabular}

EO: essential oil of $P$. myrsinites, CAE: crude acetonic extract of $P$. myrsinites, CEE: crude ethanolic extract of $P$. myrsinites.

The results of the antimicrobial activity of MIC analysis of fractions obtained from CEE, hexane, chloroform, intermediate of chloroform and ethyl acetate, and the aqueous fraction obtained with
CAE were also made from the visual reading of dishes after two hours of resazurin in the greenhouse at $\pm 35{ }^{\circ} \mathrm{C}$. The activity is also presented in Table 3 with concentrations in $\mu \mathrm{g} \cdot \mathrm{mL}^{-1}$.

Table 3. MIC of fractions of hexane, chloroform, intermediate chloroform, ethyl acetate and aqueous (CAE) of P. myrsinites against Gram-positive and Gram-negative bacteria.

\begin{tabular}{lccccc}
\hline \multirow{2}{*}{ Bacteria } & \multicolumn{5}{c}{ Fractions $\left(\boldsymbol{\mu g} . \mathbf{m L}^{-\mathbf{1}}\right)$} \\
\cline { 2 - 6 } & Hexane & Chloroform & $\begin{array}{c}\text { Chloroform } \\
\text { Intermediate }\end{array}$ & $\begin{array}{c}\text { Ethyl } \\
\text { Acetate }\end{array}$ & $\begin{array}{c}\text { Aqueous } \\
\text { (CAE) }\end{array}$ \\
\hline Sa 29213 & 500 & 1000 & 500 & 500 & 2 \\
Sa 25923 & 62.50 & 500 & 250 & 250 & 500 \\
Se 12228 & 125 & 1000 & 250 & 250 & 250 \\
Ec 25312 & $\geq 2,000$ & $\geq 2,000$ & $\geq 2,000$ & $\geq 2,000$ & $\geq 2,000$ \\
$K p$ P00603 & $\geq 2,000$ & $\geq 2,000$ & $\geq 2,000$ & $\geq 2,000$ & $\geq 2,000$ \\
$P a$ 27853 & $\geq 2,000$ & $\geq 2,000$ & $\geq 2,000$ & $\geq 2,000$ & $\geq 2,000$ \\
\hline
\end{tabular}

Sa: Staphylococcus aureus, Se: Staphylococcus epidermidis, Ec: Escherichia coli, Kp: Klebsiella pneumoniae, Pa: Pseudomonas aeruginosa, CAE: crude acetonic extract of $P$. myrsinites.

The CEE showed a MIC for $S$. aureus ATCC 29213 of $500 \mu \mathrm{g} \cdot \mathrm{mL}^{-1}$; for $S$. aureus ATCC 25923 and S. epidermidis ATCC 12228 of 125 $\mu \mathrm{g} \cdot \mathrm{mL}^{-1}$. According to the classification by Holetz et al (2002), the obtained results demonstrated that Gram-positive strains were sensitive to CEE with moderate intensity. Similarly, CAE showed antimicrobial activity against Gram-positive strains, and this was more pronounced against $S$. epidermidis ATCC 12228 and moderate against both Staphylococcus aureus strains. Neither CEE nor $\mathrm{CAE}$ showed antimicrobial activity against Gram-negative bacteria. But the essential oil of $P$. myrsinites presented MIC with values $>2,000$ $\mu \mathrm{g} \cdot \mathrm{mL}^{-1}$ against all bacteria tested, indicating the absence of antimicrobial activity for essential oil.

P. myrsinites was previously reported with three possible chemotypes, popularly known as "araçá encarnado", "araçá preto" and "araçá amarelo", which present essential oils with qualitative and quantitative variations. The compounds identified in the essential oil of the three chemotypes were neryl acetate in "araçá encarnado" and "araçá amarelo" and $\delta$-cadinol in "araçá preto", indicating that these species may have distinct biological activities, as well as morphological differences (PEREIRA, 2010).

According to Pereira (2010), the results of the antimicrobial activity by disc diffusion method indicated that only "araçá preto" showed a partially activated antimicrobial activity (inhibition zone between 9 and $12 \mathrm{~mm}$ ) against two strains of Staphylococcus aureus. As regards Gram-positive bacteria, several studies demonstrate the antibacterial activity of natural products of the species from the Psidium genus, indicating activity against $S$. aureus, and also against several other strains, among them Staphylococcus epidermidis, Bacillus subtilis, Bacillus cereus, Proteus mirabilis, Streptococcus pyogenes, Streptococcus mutans, Streptococcus salivarius, Streptococcus oralis, Lactobacillus rhamnosus, Salmonella enteritidis (GONÇALVES, ALVES FILHO; MENEZES., 2005; SANCHES et al., 2005; NAIR; CHANDA, 2007; MEDINA et al., 2011; SILVA et al, 2013; BONA et al., 2014; SCUR et al., 2014; JARDIM et 
al., 2015; ALVARENDA et al., 2015; SILVA et al., 2016).

In the case of the fractions obtained from the CEE and MIC of hexane fraction against strains S. aureus ATCC 29213, S. aureus ATCC 25923 and S. epidermidis ATCC 12228 was 500, 62.50 and $125 \mu \mathrm{g} . \mathrm{mL}^{-1}$ respectively, which provides a good antimicrobial activity against $S$. aureus ATCC 25923 and moderate for the other two Grampositive bacteria. The chloroform fraction showed moderate antimicrobial activity only against the strain S. aureus ATCC 25923 and weak activity against two other Gram-positive strains. The MICs obtained for the intermediate fraction of chloroform and ethyl acetate fractions against Gram-positive bacteria indicate a moderate antimicrobial activity.

Finally, the aqueous fraction obtained with the CAE showed a MIC value $>2,000 \mu \mathrm{g} \cdot \mathrm{mL}^{-1}$ on the strain S. aureus ATCC 29213, which indicates an inactive antimicrobial activity, while against the strains S. aureus ATCC 25923 and S. epidermidis ATCC 12228 the activity is considered moderate. The best results observed by examining the MIC were against Gram-positive strains provided by the CEE, CAE, hexane fraction, intermediate chloroform, ethyl acetate and aqueous fraction (CAE), since none of the test samples showed antimicrobial activity against Gram-negative bacteria.

\section{CONCLUSIONS}

P. myrsinites DC. is a plant with few studies that validate its pharmacological activities and elucidate its chemical composition, but its promising biological activities have been demonstrated by ethnobotanical data, highlighting the pharmacological potential of the araçá species.

The lethality tests using Artemia salina with the essential oil and the hexane fraction obtained from leaf extracts showed strong and moderate toxicity, respectively, thus encouraging further research with substances isolated from these fractions. Extracts and fractions from $P$. myrsinites leaves also showed antibacterial activity against Gram-positive strains. Thus, the results indicate that the fractions obtained from crude ethanolic and acetonic extracts may contain compounds with potential use in the treatment of pathologies caused by microbial agents.

This study contributes to the knowledge of the chemical characteristics and biological activities of Psidium species. It also indicates the importance of future studies to elucidate the secondary metabolites responsible for the biological properties of this species, in the search for therapeutic alternatives derived from Brazilian natural products.

\section{ACKNOWLEDGMENTS}

We are grateful to UEG for the Incentive Scholarship Program for Research and Scientific Production (PROBIP-UEG), to the Coordination for the Improvement of Higher Education Personnel (CAPES) for scholarships in Scientific Initiation and to the Master's degree and Research Support Foundation of State of Goiás (FAPEG).

RESUMO: Psidium myrsinites DC. é uma espécie do bioma Cerrado conhecida como "araçá" comumente utilizada como planta medicinal no tratamento de diarreias e na cicatrização devido as suas propriedades adstringentes. $\mathrm{O}$ objetivo deste trabalho foi realizar a triagem fitoquímica com propósito exploratório e a investigação da toxicidade pelo teste de letalidade em Artemia salina e da atividade antimicrobiana contra bactérias Gram-positivas e Gram-negativas pela determinação da concentração mínima inibitória do óleo essencial, dos extratos brutos acetônico e etanólico, além das frações obtidas com solventes orgânicos de polaridade crescente: hexano, clorofórmio, acetato de etila das folhas de Psidium myrsinites DC. O perfil fitoquímico determinou as principais classes de metabólitos secundários presentes como compostos fenólicos (taninos, cumarinas, flavonoides, heterosídeos antraquinônicos e compostos terpênicos. O óleo essencial e a fração hexano demonstraram nível de toxicidade forte e moderado respectivamente, incentivando assim novas pesquisas com substâncias isoladas dos mesmos. Os extratos brutos etanólico e acetônico, e as frações hexano, intermediária de clorofórmio, acetato de etila e fração aquosa do extrato bruto acetônico demonstraram melhor ação inibitória sobre o crescimento bacteriano de bactérias Gram-positivas com concentrações mínimas inibitórias variando entre 62,5 e $250 \mu \mathrm{g} \cdot \mathrm{mL}^{-1}$. Contudo, a presença de compostos secundários tais como, taninos, flavonoides e terpenos, provavelmente, está associada ao efeito inibitório sobre os micro-organismos testados, o que poderia justificar o uso medicinal das folhas dessa espécie.

PALAVRAS-CHAVE: Psidium myrsinites DC., óleos essenciais, taninos, Artemia salina, concentração mínima inibitória. 


\section{REFERENCES}

ADAMS, R. P. Identification of essential oil componentes by gas chromatography/mass spectrometry. 4. ed. Carol Stream: Allured Publishing Corporation, 2007. 804 p.

ALVARENDA, F. Q.; ROYO, V. A.; MOTA, B. F. C.; LAURENTIZ, R. S.; MENEZES, E.V.; MELO JUNIOR, A. F.; OLIVEIRA, D. A. Atividade Antinociceptiva e Antimicrobiana da Casca do Caule de Psidium Cattleyanum Sabine. Rev. Bras. Plantas Med., v. 17, n. 4, supl. III, p. 1125-1133, 2015. https://doi.org/10.1590/1983-084x/14_146

BONA, E. A. M.; PINTO, F. G. S.; FRUET, T. K.; JORGE, T. C. M.; MOURA, A. C. Comparação de métodos para avaliação da atividade antimicrobiana e determinação da concentração inibitória mínima (CIM) de extratos vegetais aquosos e etanólicos. Arq. Inst. Biol., v. 81, n. 3, p. 218-225, 2014. https://doi.org/10.1590/18081657001192012

CAMPOS, Letícia Zenóbia de Oliveira. Etnobotânica do gênero Psidium L. (Myrtaceae) no Cerrado brasileiro. 2010. 71 f. Dissertação (Mestrado em Botânica) - Instituto de Ciências Biológicas, Universidade de Brasília, Brasília, 2010.

CHAIBUB, Beatriz Abdallah. Identificação de punicalagina das folhas de Lafoensia pacari (Lytraceae) e avaliação das atividades biológicas. 2013. 113 f. Dissertação (Mestrado em Ciências Farmacêuticas), Universidade Federal de Goiás, Goiânia, 2013.

Clinical and Laboratory Standards Institute. Methodology of Sensitivity Tests to Dilution Antimicrobial Agents for Aerobic Growth Bacteria: Standard Approved. 6. ed. CLSI document M7-A6. Wayne, Pensilvânia -USA, 2010.

COELHO, S. G.; HASS, A. P. S.; POSER, G. L.; SCHAPOVAL, E. E. S.; ELISABETSKY, E. Ethnopharmacological studies of antimicrobial remedies in South of Brazil. J. Ethnopharmacol., v. 90, p. 135143, 2004. https://doi.org/10.1016/j.jep.2003.09.039

CORRÊA, L. C.; SANTOS, C. A. F.; VIANELlO, F.; LIMA, G. P. P. Antioxidant content in guava (Psidium guajava) and araçá (Psidium spp.) germplasm from different Brazilian regions. Plant Genet. Resour., v. 9, n. 3, p. 384-391, 2011. https://doi.org/10.1017/S1479262111000025

COSTA, Aloísio Fernandes. Farmacognosia. 3. ed. Lisboa: Fundação Calouste Gulbenkian, 2001. 1036 p.

DIAS, C. N.; ALVES, L. P. L.; RODRIGUES, K. A. F.; BRITO, M. C. A.; ROSA, C. S.; AMARAL, F. M. M.; MONTEIRO, O. S.; ANDRADE, E. H. A.; MAIA, J. G. S.; MORAES, D. F. C. Chemical Composition and Larvicidal Activity of Essential Oils Extracted from Brazilian Legal Amazon Plants against Aedes aegypti L. (Diptera: Culicidae). J. Evid. Based Complementary Altern. Med., 2015. https://doi.org/10.1155/2015/490765

FALKENBERG, M. B.; SANTOS, R. I.; SIMÕES, C. M. O. Introdução à análise fitoquímica. In: SIMÕES, C.M.O.; SCHENKEL, E. P.; GOSMANN, G.; MELLO, J. C. P.; MENTZ, L. A.; PETROVICK, P. R. Farmacognosia: da planta ao medicamento. 6. Ed. Florianópolis: Editora da UFSC; Porto Alegre: Editora da UFRGS, cap 10, p. 229-244, 2010.

FAUTH, S.; CAMPOS, A. R.; SILVEIRA, E. R.; RAO, V. S. Efeitos de óleos essenciais de plantas no tempo de sono induzido por cetamina em camundongos. Rev. Bras. Farmacogn., v. 12, p. 112-113, 2002. https://doi.org/10.1590/S0102-695X2002000300052

FRANZON, Rodrigo Cezar; CAMPOS, Letícia Zenóbia de Oliveira; PROENÇA, Carolyn Elinori Barnes SOUSA-SILVA, José Carlos. Araçás do gênero Psidium: principais espécies, ocorrência, descrição e usos. Planaltina/DF: Embrapa Cerrados, 2009. 48 p. 
FREITAS, M. O.; MORAIS, S. M. D.; SILVEIRA, E. R. Volatile constituents of Psidium Myrsinoides O. Berg. J. Essent. Oil Res., v. 14, n. 5, p. 364-365, 2002. https://doi.org/10.1080/10412905.2002.9699885

GONÇALVES, A. L.; ALVES FILHO, A.; MENEZES, H. Estudo comparativo da atividade antimicrobiana de extratos de algumas árvores nativas. Arq. Inst. Biol., v. 72, n. 3, p. 353-358, 2005.

IHA, S. M.; MIGLIATO, K. F.; VELLOSA, J. C. R; SACRAMENTO, L. V. S.; PIETRO, R. C. L. R.; ISAAC, V. L. B.; BRUNETTI, I. L.; CORRÊA, M. A.; SALGADO, H. R. N. Estudo fitoquímico de goiaba (Psidium guajava L.) com potencial antioxidante para o desenvolvimento de formulação fitocosmética. Rev. Bras. Farmacogn., v. 18, n. 3, p. 387-393, 2008. https://doi.org/10.1590/S0102-695X2008000300013

HOLETZ, F. B.; PESSINI, G. L.; SANCHES, N. R.; CORTEZ, D. A. G.; NAKAMURA, C. V.; DIAS FILHO, B. P. Screening of some plants used in the Brazilian Folk Medicine for the treatment of infectious diseases.

Mem. Inst. Osvaldo Cruz, v. 97, n. 7, p. 1027-1031, 2002. https://doi.org/10.1590/S007402762002000700017

JARDIM, E. C. G.; JARDIM JÚNIOR, E. G.; SCHWEITZER, C. M.; OKAMOTO, A. C. Atividade inibitória do verniz de araçá (Psidium cattleianum Sabine) sobre amostras de Streptococcus mutans "in vitro". Arch. Health Invest., v. 4, n. 6, p. 54-60, 2015.

LEITE, N. F.; SOBRAL-SOUZA, C. E.; MATIAS, E. F. F.; ALENCAR, L. B. B.; ALBUQUERQUE, R. S.; MORAIS-BRAGA, M. F. B.; SOUZA, E. O.; COUTINHO, H. D. M. Citoprotective effect of Eugenia jambolana and Psidium myrsinites DC. A. against the lipid peroxidation induced by iron II. Acta Toxicol. Argent., v. 24, n. 3, p. 187-192, 2016.

LENNETTE, E. H.; BALOWS, A.; HAUSLER, W. J.; SHADOMY, H. J. Manual of Clinical Microbiology. American Society for Microbiology: Washington, D.C., 1985. 1149 p.

MATOS, Francisco José de Abreu. Introdução à fitoquímica experimental. 3. Ed. Fortaleza: UFC, 2009. 150 p.

MATOS, J. M. D.; MATOS, M. E. Farmacognosia. Fortaleza: UFC, 1989. 245 p.

MEDINA, A. L.; HAAS, L. I. R.; CHAVES, F. C.; SALVADOR, M.; ZAMBIAZI, R. C.; SILVA, W. P.; NORA, L.; ROMBALDI, C. V. Araçá (Psidium cattleianum Sabine) fruit extracts with antioxidant and antimicrobial and antiproliferative effect on human cancer cells. Food Chem., v. 128, p. 916-922, 2011. https://doi.org/10.1016/j.foodchem.2011.03.119

MEDEIROS, Fernando César Magalhães. Caracterização química e atividade biológica de óleos essenciais de plantas do Cerrado contra fungos xilófagos. 2014. 108 f. Dissertação de Mestrado. Departamento de Engenharia Florestal. Universidade de Brasília, Brasília, 2014.

MOLINAS-SALINAS, G. M.; SAID-FERNÁNDEZ, S. A modified microplate citotoxicity with brine shrimp larvae (Artemia salina). Pharmacology, v. 3, p. 633-638, 2006.

NAIR, R.; CHANDA, S. In-vitro antimicrobial activity of psidium guajava L. leaf extracts against clinically important pathogenic microbial strains. Braz. J. Microbiol., v. 38, p. 452-458, 2007. https://doi.org/10.1590/S1517-83822007000300013

NGUTA, J. M.; MBARIA, J. M.; GAKUYA, D. W.; GATHUMBI, P. K.; KABASA, J. D.; KIAMA, S. G. Biological screening of Kenyan medicinal plants using Artemia Salina L. (Artemiidae). Pharmacology, v. 2, p. 458-78, 2011.

OLIVEIRA, V. B., YAMADA, L. T., FAGG, C. W., BRANDÃO, M. G. L. Native foods from Brazilian biodiversity as a source of bioactive compounds. Food Res. Int. v. 48, p. 170-179, 2012.

https://doi.org/10.1016/j.foodres.2012.03.011 
PAULA, J. A. M.; FERRI, P. H.; BARA, M. T. F.; TRESVENZOL, L. M. F.; SÁ, F. A. S.; PAULA, J. R. Infraspecific chemical variability in the essential oils of Pimenta pseudocaryophyllus (Gomes) L.R. Landrum (Myrtaceae). Biochem. Syst. Ecol., v. 39, p. 643-650, 2011. https://doi.org/10.1016/j.bse.2011.05.013

PATEL, S. Exotic tropical plant Psidium cattleianum: a review on prospects and threats. Rev. Environ. Sci. Bio., v. 11, p. 243-248, 2012. https://doi.org/10.1007/s11157-012-9269-8

PEREIRA, C. K. B. Estudo químico e atividades microbiológicas de espécies do gênero Psidium (Myrtaceae). 2010. 120 f. Dissertação (Mestrado) - Programa de Pós Graduação em Bioprospecção Molecular. Universidade Regional de Cariri, Cariri, 2010.

RAHMAN, Atta-ur; CHOUDHARY, M. I.; THOMSEN, W. J. Bioassay Techniques for Drug Development. 1. ed. Singapure: Taylor \& Francis e-Library, 2005. 203 p.

SANCHES, N. R.; CORTEZ, D. A. G.; SCHIAVINI, M. S.; NAKAMURA, C. V.; DIAS FILHO, B. P. An Evaluation of Antibacterial Activities of Psidium guajava (L.). Braz. Arch. Biol. Technol., v. 48, n. 3, p. 429436, 2005. https://doi.org/10.1590/S1516-89132005000300014

SÁNCHEZ, L., NEIRA, A. Bioensayo general de letalidad en Artemia salina, a las fracciones del extracto etanólico de Psidim guajava L. y Psidium guineense Sw. Cultura Científica, p. 40-45, 2005.

SCUR, M. C.; PINTO, F. G. S.; PANDINIA, J. A.; COSTA, W. F.; LEITE, C. W.; TEMPONI, L. G. Antimicrobial and antioxidant activity of essential oil and diferente plant extracts of Psidium cattleianum Sabine. Braz. J. Biol., v. 76, n. 1, p. 101-108, 2016. https://doi.org/10.1590/1519-6984.13714

SILVA JÚNIOR, Manoel Cláudio. 100 árvores do Cerrado: guia de campo. Brasília: Rede de sementes do Cerrado, 2005. 278 p.

SILVA, M. V. S.; FRAZÃO, T. S.; FERREIRA, M. M. A.; VIEIRA, D. B.; DO VALE, R. F. F.; CARMO, L. H.; YANO, T.; FIGUEIREDO, P. M. Assessment in Vitro of Antibacterial Activity of Manipulated Product, on Solution Form, Obtained from Dry Extract of Leaves of Psidium guajava L. Int. J. Chem., v. 8, n. 1, p. 64-73, 2016. https://doi.org/10.5539/ijc.v8n1p64

SILVA, R. M.; DOURADO, M. R.; PENHA, M. Q.; CAMPOS, L. G.; CARVALHO, M. F. F.; PIRES JÚNIOR, D. R. Susceptibilidade microbiana de bactérias e fungos frente ao extrato de Psidium guajava L.: avaliação in vitro. Arq. Odont., v. 49, n. 2, p. 60-65, 2013.

SOARES-SILVA, L. H.; PROENÇA, C. E. B. A new species of Psidium L. (Myrtaceae) from southern Brazil. Bot. J. Linn. Soc., v. 158, p. 51-54, 2008. https://doi.org/10.1111/j.1095-8339.2008.00727.x

VAN DEN DOOL, H., KRATZ, P. D. A generalization of the retention index system including linear temperature programmed gas_-liquid partition chromatography. J. Chromatog. A, v. 11, p. 463-471, 1963. https://doi.org/10.1016/S0021-9673(01)80947-X

VOSS-RECH, D.; KLEIN, C. S.; TECHIO, V. H.; SCHEUERMANN, G. N.; RECH, G.; FIORENTIN, L. Antibacterial activity of vegetal extracts against serovars of Salmonella. Ciênc. Rural, v. 41, n. 2, p. 314-320, 2011. 